\title{
The Reflection of Online learning using WhatsApp in Elementary Schools during the Covid-19 Pandemic
}

\author{
Kusriyati $^{1}$, Wakhudin ${ }^{2}$ \\ \{ kusriyati99@gmail.com¹‥wakhudin@ump.ac.ad² ${ }^{2}$ \} \\ ${ }^{1}$ Sekolah Dasar Negeri 1 Kasegeran, Banyumas \\ ${ }^{2}$ Magister Pendidikan Dasar, Universitas Muhammadiyah Purwokerto
}

\begin{abstract}
The World Health Organization (WHO) has declared Covid-19 as pandemic, and its pushing almost all institutions to migrate to the online platforms, including education activities. WhatsApp is one of application that works over different stages and is broadly utilized among teacher, student, and parent. The paper aims to explained and obtain information on online learning information using WhatsApp in elementary school and the problem encountered by students in learning during the Covid-19 pandemic. The qualitative research method used is descriptive qualitative. The qualitative data used a purposive sampling technique or sampling-based on specific objectives. The data collected, analyzed, and conclude to acquiring the reference as a literature study. The analysis finds that The necessity of WhatsApp for online learning assiststhe teacher to provide materialsand assignment for the student. But the effectiveness due to higher education only. This kind of app in elementary or primary school needed support from parents in learning activities. Unpreparedness to implement several components for online learning advance the adequacy of this learning strategy. It is vital to correct with the capacities of educator, understudy, and parent in giving online office to decrease the deterrents within the learning handle.
\end{abstract}

Keywords: whatsapp, elementary school, covid-19, online learning

\section{Introduction}

The viruscalled Covid-19 spreads at the end of 2019 affected lives throughout the world. On March11, 2020, The World Health Organization (WHO) announced that Covid-19 was declared a pandemic. The pandemic with the additional announcement of social distancing as a means of restraining the spread has an impact on the global economy, sports activities, and school by pushing all institutions to migrate to online platforms [1].UNESCO says that 300 million understudies have disturbed school exercises and transitory school closures due to wellbeing and emergency [2]. Moving from ordinary instruction to virtual learning seem not happen overnight. This change inspires different obstacle and rebellion in it [3]. The educator is required to use available technology.However, it isnot only giving tasks via social media but also makinginnovation to encourage teacher's interaction with studentsso that the terminal objective can be achieved [4].

The application of technology in education includes a positive and negative affect on its client. Based on the Indonesian Internet Network Providers Association (APJII) survey, almost 24.4 million of 132.7 million Indonesian people associated to the web, especially at the age of 10-24 years[5]. Online learninghas been used on the level of the auxiliary and higher instruction who as of now get it the utilize of innovation [3][6][7]. Due to the impact of the pandemics, the necessity of online learning for elementary school students escalate. In order not to affect the 
regular teaching progress, the school actively respond to national policies, advocates students to learn independently, and uses the various internet application to achieve "School's Out, But Class's On"'[8].Media online usage or multimedia-based is one of the solutions to make pupils understand the material well[9].

Online learning is characterized as "learning encounters in synchronous or nonconcurrent situations utilizing diverse gadgets (e.g.,portable, tablet, etc.) with web get to. In these situations, understudies can be anyplace to memorize and connected with teaches and other students" [10]. Personal attention is a huge issue facing online learning, the flexibility of time, and the adversity towards technologies based on connection, installation, and hardware. The key to the victory of instruction is held by the educator since the instructor straightforwardly touches understudies in teaching [5]. The choice of various methods in online learning by the teacher shouldbasedon the student characteristics themselves.

The effectiveness of teaching and learning activity must be consider. Itmeans how far the aim of the activity can be reached [11].Recently, our ways of communication shift to instant massaging (IM) apps on a mobile phones. Among several kinds of IM, WhatsApp, a crossplatform mobile messaging app, has become very popular and has more than one billion monthly active users[7]. This application is being used among the student to send multimedia messages like the photos, videos, audio along with simple text messages. There's too an unmistakable prove, that this app contains a noteworthy potential to bolster the learning handle and features a major suggestions on pedagogies [12]. WhatsApp offers the opportunity for online cooperation and teamwork among students. Therefore, it has emerged for students to share information and discussion when they are miles away. Teaching and learning process need teaching aids (lesson plans, syllabus,etc.),media (technology), approach, and teaching method to reach the effectiveness of teaching-learning process [13].

Itis exciting and essential toresearch the effectiveness of teaching-learning process using Whatsapp[14].A few recent research studies have explored the adequacy of online learning from higher instruction understudies amid pandemics [3][15]. Another research is trying to discover out the challenges of giving online learningand the quality of various app including WhatsApp[6][7][12].Moreoverhow the objective condition by applying online learning on elementary school[5][8].

\section{Methods}

The qualitative research method used is descriptive qualitative. The purpose of this descriptive research is to make descriptions, or paintings systematically, factually, and accurately regarding the facts, characteristics, and relationships between theinvestigated phenomena. The qualitative data used a purposive sampling technique or sampling-based on specific objectives. The study population was defined as a fixed variable, namely students of SDN 1 Kasegeran. Grade V samples were tookas a representation of high-grade students. The data collection methoduses interviewsto obtain information related to online learning using WhatsApp.

\section{Result and Analysis}

The enforcement of online learning is most cases using WhatsApp application[2][7][12] with the consideration that almost every teachers, students, and parent have this application on their phone. The group feature in the application facilitates the discussion and sharing of documents among teacher and student. The teachers provide materials and assignments on it then the students submittheir completed work here too. Based on Malhotra \& Bansal [7], more than $90 \%$ of students were used WhatsApp for educational purposes. A 
similar positive attitude is facilitator's availability and learning anytime anywherethrough WhatsApp with $86.7 \%$ students in Gon \& Rawekar[12].The combination of mediums like recordings, pictures, and voice notes, along side the steady accessibility of facilitators and learning anytime anyplace, has made WhatsApp a unused and helpful apparatus for instructing and learning exercises.The strengths of online learning occur on time flexibility, location flexibility, expansive audience and content, and immediate feedback.

However, Fauzi \&Khusuma [5] appears that $80 \%$ of educator feel disappointed based on ineffectiveness implementation online learning in elementary school. Whatsapp media is seen as unseemly media since it isn't set to remove course learning or online learning for low-level instruction. Ineptness to do online learning is the reason for learning to be ineffectual. It is since online learning is seen as something troublesome to execute, require a few components to be able to do like offices, internet access, preparation to memorize (instructor, understudies, and fabric) and parent collaboration.

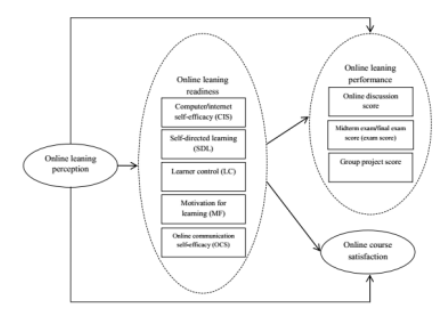

Fig 1. Online Learning Recognition

The picture appears that online learning preparation would altogether influence understudy execution and fulfillment. The teacher's part in building online learning availability is the key to learning victory. The step taken is that instructors inquire offer assistance from guardians, and more seasoned understudies incorporate coordination and interaction within the frame of video calls and documentation. In differentiate, understudy learning exercises carried out at domestic [2].

The majority of the students lackaccess to internet facilities, owing to the constrained assets of instructive teach and guardians, as it were a few teach were able to present viable online classes amid a widespread. One of the less talked about regions of online instruction is the require for inspiration for online learning. $71.4 \%$ of understudies detailed that learning within the routine classroom was more persuading than separate learning[3]. It shown that the lion's share of understudies, can oversee their consider time successfully online and can rapidly total assignments in time, but total courses cannot be completed online. Be that as it may, when it comes to doing gather assignments without confront to confront discourse with the bunch individuals, they confront numerous issues, as reposted by $42.9 \%$ of respondents [3].Due to the different family conditions of the students, it is impossible to achieve online learning that all students can participate. Challenges related to understudies are restricted communication and outreach among understudies, higher challenges for guardians concerned almost a need of teach at-home learning. More time went through making a difference their children consider at domestic, particularly for children at essential school, need of innovation abilities, and overwhelming web bills [2]. 
So the availability and value in giving quality learning with the assistance of ICT-based innovations is still a huge challenge for a nation like Indonesia. Other than, it has been found that online learning requires efficient arranging, planning, and cautious details of the points and objectives of instruction to form an compelling learning environment. The developed countries may be having the advantage of initiating emergency online and remote teaching during a crisis phase. However, the same may not be apply to all countries of the world. Instead of starting unplanned online learning and rushed way, understanding student's items of common sense, and their needs, their inclinations, and challenges had to be sketched out already [6].

SDN 1 Kasegeran is located on Jalan Raya Kasegeran KM.5, Cilongok District, Banyumas Regency. The curriculum used is the 2013 curriculum. with the Covid-19 pandemic changing face-to-face learning into online learning. The application used is WhatsApp. Based on the interview, the WhatsApp application is the easiest to use by students and teachers. With various factors, the constraints are due to the economic condition of the parents, knowledge, signals, and quotas, but online learning has been implemented. Todetermine thesample, observations were made by interviewing the fifth-grade teacher as colleagues in the research process. Initial observations held on April 5, 2021. Of the 16 population of grade V students, we took three representative samples.

Theinitial conditions for online learning using the WhatsApp application during the Covid19 pandemic, out of 16 students, eight students $(50 \%)$ who are active in learning, and as many as seven students (43.75\%) who are sometimes active in learning, and one student $(6.25 \%)$, who are not active because the student is constrained by not having an Android cellphone.The research in the fifth grade of SDN 1 Kasegeran, in the online learning process the teacher always active in providing material, also always provides opportunities for students to ask questions. Some studentswere diligent in asking questions and actively commenting on learning.In the midnight, students usually still privat chat when they did not understand the tasks. However, out of 16 students, there is one student who doesnot have a smartphone, so he rarely submits assignments. To diagnose the need for online learning through the WhatsApp application, the teacher prepares before learning and repeats the material. They are looking for relevant sources, both electronic books/e-books, as well as ongoing problems / hot and updated information, or sharedthe youtube links to students via the WhatsApp application. Once a week, doing a daily assessment. Whatsapp applications that are easy to use our chat, voice notes, video calls are rare. According to him, online learning by implementing the WhatsApp application is efficient because there is no need to use too much data, and the signal does not have to be strong.

Interviews with three students showed the results of the study results that in the online learning process through the WhatsApp application, students always expressed their opinions, andstudents immediately learned when there was a task given by the teacher. Students review the material provided by the teacher, and online learning through the WhatsApp application makes students motivated to study harder when they get small test scores. Students prepare learning equipment before learning begins so that if in learning, they are ready to do assignments/tests online. Students feel happy when given assignments by the teacher, they are always ready, and if the teacher suddenly asks students questions, the students will try to answer as much as they can. Online learning through the WhatsApp application makes them comfortable following the learning activity, because the WhatsApp platform is easily accessible. 


\section{Conclusion}

The Covid-19 widespread has changed the way a few individuals get, and give instruction. The necessity of WhatsApp for online learning assists the teacher to provide materials like videos, documents and assignment for the student. But the effectiveness due to higher educationonly. This kind of app in elementary or primary school needed support from parents in learning activities. We cannot disregard the understudies who don't have get to to online innovation, especially in Indonesia. Unpreparedness to implement of several components for online learning promt the viability of this learning strategy. Instructors are gathered to find the fitting ways to advance the learning prepare scholastically and socio-emotional. Online learning frameworks utilizing the advanced stages at the essential school level tend to alter the confront of the way better instruction strategies, more viable, and pleasant. In any case, it is fundamental to straighten out with the capacities of educator, understudy, and parent in giving online office to diminish the impediments within the learning handle.

\section{References}

[1] Schneider SL, Council ML. Distance learning in the era of COVID-19. Archives of dermatological research. $2021 \mathrm{Jul} ; 313(5): 389-90$.

[2] Suryaman M, Cahyono Y, Muliansyah D, Bustani O, Suryani P, Fahlevi M, Munthe AP. COVID-19 pandemic and home online learning system: Does it affect the quality of pharmacy school learning. Systematic Reviews in Pharmacy. 2020;11(8):524-30.

[3] Adnan M, Anwar K. Online Learning amid the COVID-19 Pandemic: Students' Perspectives. Online Submission. 2020;2(1):45-51.

[4] Sirri EL, Lestari P. Implementasi Edpuzzle Berbantuan WhatsApp Group Sebagai Alternatif Pembelajaran Daring Pada Era Pandemi. JPMI (Jurnal Pendidikan Matematika Indonesia). 2020 Sep 1;5(2):67-72..

[5] Fauzi I, Khusuma IH. Teachers' elementary school in online learning of COVID-19 pandemic conditions. Jurnal Iqra': Kajian Ilmu Pendidikan. 2020 Jun 6;5(1):58-70..

[6] Bordoloi R, Das P, Das K. Perception towards online/blended learning at the time of Covid-19 pandemic: an academic analytics in the Indian context. Asian Association of Open Universities Journal. 2021 Feb 16.

[7] Malhotra DK, Bansal S. Magnetism of WhatsApp among veterinary students. The Electronic Library. 2017 Nov 6; 1-10.

[8] Xie Z, Yang J. Autonomous learning of elementary students at home during the COVID-19 epidemic: A case study of the Second Elementary School in Daxie, Ningbo, Zhejiang Province, China. Ningbo, Zhejiang Province, China (March 15, 2020). 2020 Mar 15..

[9] Mustakim M. Efektivitas pembelajaran daring menggunakan media online selama pandemi covid-19 pada mata pelajaran matematika. Al asma: Journal of Islamic Education. 2020;2(1):1-12.

[10] Dhawan S. Online learning: A panacea in the time of COVID-19 crisis. Journal of Educational Technology Systems. 2020 Sep;49(1):5-22..

[11] Hikmat H, Hermawan E, Aldim A, Irwandi I. Efektivitas pembelajaran daring selama masa pandemi Covid-19: Sebuah survey online. LP2M. 2020, 1-7.

[12] Gon S, Rawekar A. Effectivity of e-learning through WhatsApp as a teaching learning tool. MVP Journal of Medical Sciences. 2017 May 22;4(1):19-25.

[13] Saragih EM, Ansi RY. Efektivitas penggunaan whatsapp group selama pandemi covid-19 bagi pelaku pendidik. InSeminar Nasional Multi Disiplin Ilmu Universitas Asahan 2020 Oct 16. 207-212.

[14] Daheri M, Juliana J, Deriwanto D, Amda AD. Efektifitas whatsapp sebagai media belajar daring. Jurnal Basicedu. 2020 Jun 29;4(4):775-83..

[15] Adedoyin OB, Soykan E. Covid-19 pandemic and online learning: the challenges and opportunities. Interactive Learning Environments. 2020 Sep 3:1-14. 